\title{
A scientometrics study on green building: A DEA application
}

\author{
Soheil Sadi-Nezhad ${ }^{a^{*}}$
}

${ }^{a}$ School of Management, New York Institute of Technology, 1700 - 701 W Georgia St., Vancouver, BC V7Y 1 K8 Canada

CH R O N I C LE A B S T RACT

Article history:

Received: March 82019

Received in revised format: April 22019

Accepted: April 22019

Available online:

April 32019

Keywords:

Green construction

Green building

Green project

$D E A$

Hong Kong

Singapore

Data envelopment analysis

$\mathrm{CO}_{2}$

\begin{abstract}
Construction operations are blamed as one of important causes of green gas effects. During the past few decades, there has been tremendous efforts to reduce the negative effects of construction operations on environment. This paper presents an application of data envelopment analysis to measure the relative efficiencies of the researches accomplished by various countries around the world on green construction or green management. The study expects countries that produce higher amount of $\mathrm{CO}_{2}$ accomplish more quality research articles. To do this, the study performs a survey using three keywords; namely "green construction", "green building" and "sustainable building" on Scopus database and found 8692 articles over the period 1965-2019 where one of these keywords, at least, was used in their abstracts, keywords or titles. We also use three measures of $h$-index, $I-10$ and total publications representative of quality and quantity of the outputs produced by researchers. The study considers 28 countries responsible for at least $90 \%$ of $\mathrm{CO}_{2}$ emission for measuring the relative efficiency program using data envelopment analysis. The results indicate that Hong Kong was the only efficient country followed by Singapore with relative efficiency of 0.67 .
\end{abstract}

(C) 2019 by the authors; licensee Growing Science, Canada.

\section{Introduction}

Green building, green construction or sustainable building are some common words associated with a structure and the application of processing it which are environmentally friendly and efficient throughout a building's life-cycle. Green building covers all operations from planning to design, construction, operation, maintenance, renovation, and demolition operations of the buildings (Meyer, 2009). To reach this objective, we need to build a good relationships among the contractor, the architects, the engineers, and the clients through different stages of the constructions (Ding, 2008). Green building combines various efforts to reduce and ultimately to eliminate the effects of buildings on the environment and human's healthcare. It takes advantage of renewable resources such as sunlight through passive solar, plants and trees through green roofs, rain gardens, and reduction of rainwater run-off to save electricity. There are literally various techniques used such as low-impact building materials or permeable concrete to enhance replenishment of ground water (Ortiz et al., 2009).

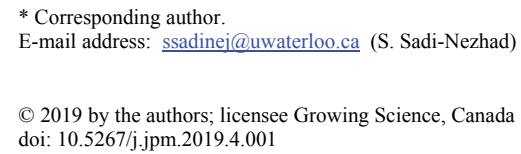


During the past few decades, there have been tremendous efforts on green building (Kuo \& Sullivan, 2001). Zuo and Zhao (2014) presented a comprehensive review on green building. Shaikh et al. (2014) presented a state-of-the-art review on optimized control systems for building energy and comfort management of smart sustainable buildings. Evins (2013) studied on all computational optimization techniques implemented for sustainable building design. Wang et al. (2005) presented a multi-objective optimization model to help designers in green building design by considering. Ali and Al Nsairat (2009) shed light on the concept of green building evaluation technique and its effect for reaching sustainable development through developing an effective green building rating system for residential units in Jordan. Corinaldesi and Moriconi (2009) investigated the effect of mineral additions on the performance of $100 \%$ recycled aggregate concrete. They concluded that satisfactory concrete properties is under development in different industries with recycled fine by choosing appropriate combination of the concrete materials. Leaman and Bordass (2007) discussed whether explored sources of occupant dissatisfaction, and whether or not green buildings were perceived as better method by their users and concluded that users most likely tolerate deficiencies rather more than they did with more conventional buildings.

\section{The proposed study}

This paper implements data envelopment analysis (DEA) to measure the relative efficiency of similar possibly non-financial units (Charnes et al., 1984; Lertworasirikul et al., 2003; Halkos \& Salamouris, 2004; Adler et al., 2002). The survey looks at various inputs and outputs and by considering some weights for the inputs/outputs, measures the relative efficiency of various units. DEA has been extensively implemented for studies in green building (Zhou et al., 2013). Vyas et al. (2017) used DEA technique for benchmarking green building attributes to reach cost effectiveness. Liu et al. (2019) used DEA for the coordinated development of green building. Liu (2015) used DEA method for a green building evaluation modeling. The proposed model of this paper uses a DEA model to do a scientometrics study on efforts accomplished by authors from different countries. Fig. 1 shows the structure of the proposed study of this paper.

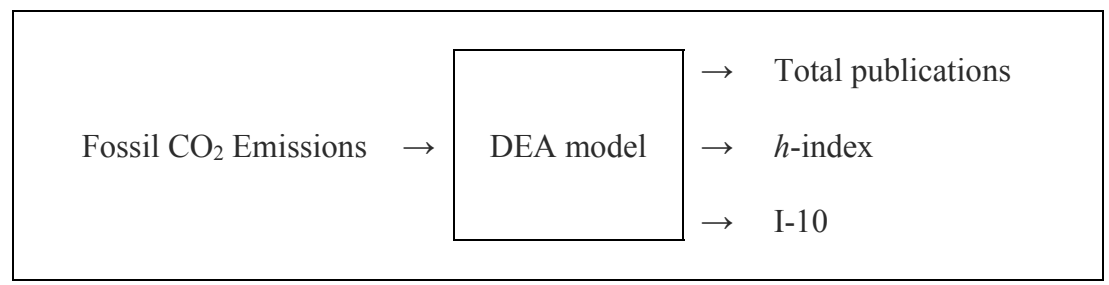

Fig. 1. The structure of the proposed method

As we can see from the results of Fig. 1, Fossil $\mathrm{CO}_{2}$ emissions in million ton per year is taken into account as the input, which means the more $\mathrm{CO}_{2}$ emissions generated by a country, the stronger commitment for doing research on carbon dioxide emission. The proposed method also determines three outputs as scientometrics data; namely total publications to measure quantity, $h$-index and $I$ 10 , as a quality of research works, for measuring the effects of the studies published by each country. The output "Total publications" covers all papers published indexed in Scopus database over the period 1959-2019 with one of the keywords of "green construction", "sustainable building" "green building" in the title, keyword or abstract. Our survey has determined 8692 records of data. Next, we filtered the data based on each country and determined $h$-index and $I-10$ statistics. In our survey, the number of publications with at least 10 citations represents $I-10$ index while $h$-index is defined as the maximum value of $h$ such that the given author(s) has published $h$-articles that have been cited at least $h$ times (McDonald, 2005).

Table 1 presents the summary of the data implemented for the proposed study of this paper. According to Table 1, the United States has published 2084 articles where the country has published at least 62 articles received 62 times of citations and maintains 405 articles where each article has 
received at least 10 citations. The country produced 5,107.39 million ton $\mathrm{CO}_{2}$ in 2017. These 28 countries have produced about $90 \%$ of the fossil emissions per year 2017 . Thus, it is important to learn how serious they are in doing research for reducing the effect of green gas effect. The implementation of DEA has provided the relative efficiency of 28 countries and Fig. 2 presents the results of our survey.

\section{Table 1}

The summary of the input/output data

\begin{tabular}{|c|c|c|c|c|}
\hline Country & $\mathrm{Mt} \mathrm{CO}_{2} /$ Year Fossil Emission Per year $2017^{*}$ & Total publication & h-index & $\mathrm{I}-10$ \\
\hline China & $10,877.22$ & 1377 & 38 & 146 \\
\hline United States & $5,107.39$ & 2084 & 62 & 405 \\
\hline India & $2,454.77$ & 284 & 16 & 24 \\
\hline Russia & $1,764.87$ & 63 & 7 & 3 \\
\hline Japan & $1,320.78$ & 95 & 12 & 17 \\
\hline Germany & 796.529 & 221 & 25 & 46 \\
\hline South Korea & 673.324 & 170 & 19 & 33 \\
\hline Iran & 671.45 & 56 & 7 & 7 \\
\hline Saudi Arabia & 638.762 & 48 & 10 & 12 \\
\hline Canada & 617.301 & 339 & 37 & 91 \\
\hline Indonesia & 511.327 & 92 & 6 & 4 \\
\hline Mexico & 507.183 & 18 & 4 & 1 \\
\hline Brazil & 492.791 & 83 & 13 & 11 \\
\hline South Africa & 467.654 & 67 & 10 & 10 \\
\hline Turkey & 429.563 & 104 & 12 & 10 \\
\hline Australia & 402.253 & 387 & 29 & 105 \\
\hline United Kingdom & 379.15 & 504 & 41 & 140 \\
\hline Italy & 361.176 & 298 & 28 & 69 \\
\hline France & 338.193 & 96 & 16 & 23 \\
\hline Poland & 319.028 & 94 & 6 & 3 \\
\hline Spain & 282.364 & 129 & 18 & 11 \\
\hline Taiwan & 279.74 & 229 & 17 & 29 \\
\hline Thailand & 279.296 & 45 & 7 & 7 \\
\hline Kazakhstan & 266.207 & 5 & 1 & 0 \\
\hline Malaysia & 258.783 & 387 & 19 & 45 \\
\hline Egypt & 258.668 & 88 & 9 & 7 \\
\hline Netherland & 174.770 & 136 & 22 & 40 \\
\hline Hong Kong & 44.715 & 231 & 33 & 97 \\
\hline Singapore & 55.018 & 131 & 27 & 39 \\
\hline
\end{tabular}

*https://en.wikipedia.org/wiki/List_of_countries_by_carbon_dioxide_emissions

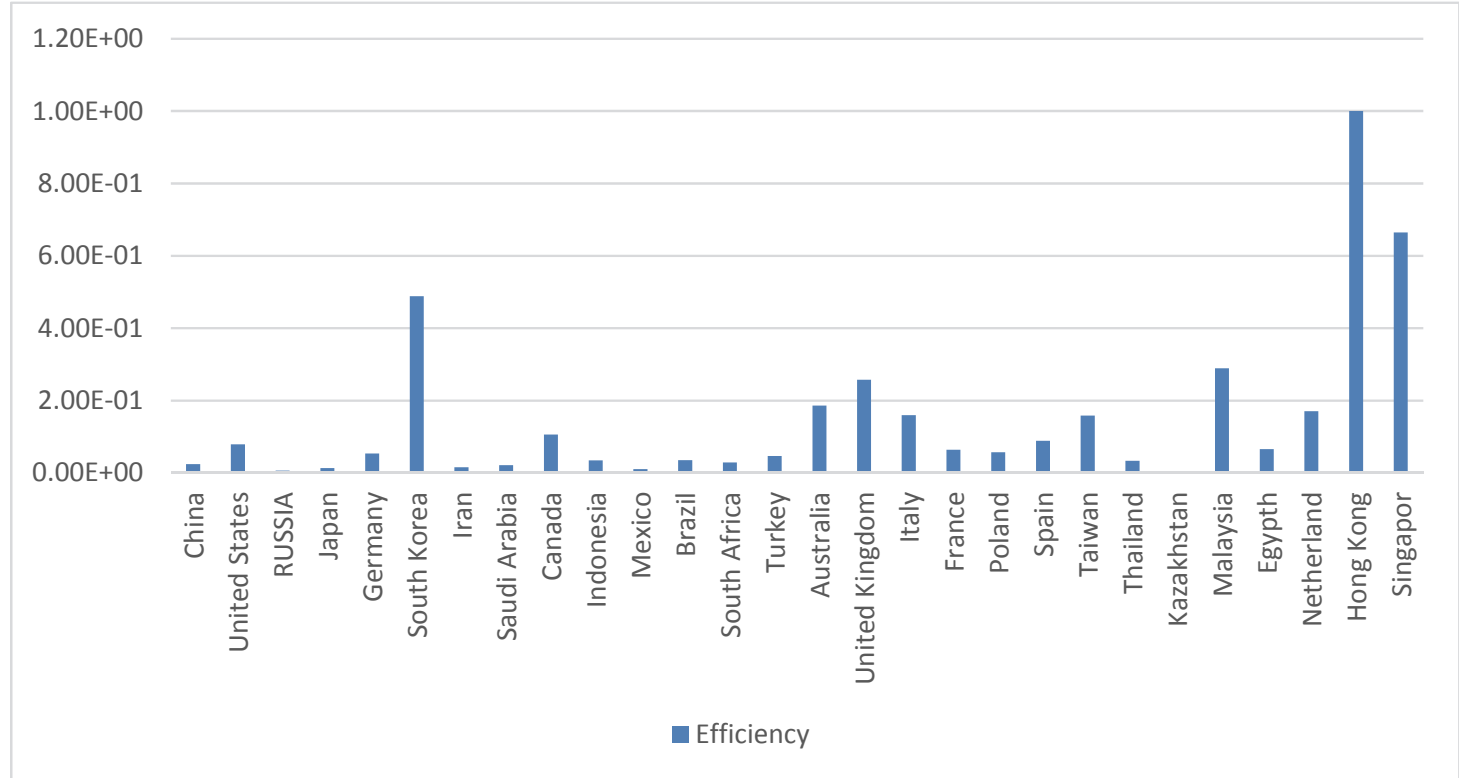

Fig. 2. The results of measuring the relative efficiency of different countries 


\section{Discussion}

According to the results of Fig. 2, Hong Kong has been considered efficient compared with other countries in terms of presenting higher good quality papers generating less than one percent of total carbon dioxide emissions (Zhang et al., 2011; Li et al., 2006). It means that Hong Kong based researchers have been more serious about global warming. On contrast, China and the United States which are responsible for about $55 \%$ of global carbon dioxide emissions have performed poorly in terms of contributing high quality achievements for scientific society. The other observations is that some developing countries such as Singapore (efficiency $=0.67$ ), South Korea (efficiency $=0.49$ ) and Malaysia with relative efficiency of about 0.29 have maintained fair contribution to scientific community despite the fact that they were not blamed by generating significant amount of $\mathrm{CO}_{2}$ emissions. China produced about 5107 million ton $\mathrm{CO}_{2}$ in 2017 which is almost half of the pollution generated by China but maintained an efficiency of about $24 \%$. Although the number seems to be better than the United States with an efficiency of $7.8 \%$ but it is about the same as many other European countries such as United Kingdom with relative efficiency of 0.26 and Netherland with relative efficiency of 0.17 . The results have shown that China and United States which are representative for more than half of green gas effect are not as serious as many other developing or developed countries for supporting scientific studies on green building.

In terms of high quality papers from Hong Kong, Qi et al. (2010) identified important factors influencing contractors to adopt green construction practices. They reported that managerial concern was the most important driver for the adoption of green practices. They also found a significant relationships between government regulations and business size with the adoption of green construction practices. According to Chan et al. (2009), green building (GB) is associated with sustainability and GB and the concept of sustainability need to be investigated for environmental concerns since their business rationale and related social concerns need to be fully explored. Chan et al. (2009) reviewed the situation of GB market in association with the general building market from the perspective of building designers. Moreover, the factors which enhance the GB were explored and the barriers which hinder its market were investigated. Chau et al. (2010) performed an investigation to estimate the effect of green experience on preferences and willingness-to-pay for green building attributes on some experiments. Tam et al. (2004) performed an investigation on green construction assessment for environmental management in the construction industry.

\section{Conclusion}

This paper has presented an implementation of DEA method to compute the relative efficiency of 28 countries which are accounted for at least $80 \%$ of carbon dioxide emissions. The study has attempted to measure the impacts of high quality articles in this area using two scientometrics figures; namely $h$-index and $I-10$. The results have disclosed that while many developing countries such as Hong Kong, Singapore and Malaysia have successfully contributed scientific achievements on green building, many developed countries such as China and United States have performed poorly. It happens that some selected European countries have been published quality articles on sustainable buildings. Singapore was an Asian country with efficient scientific production in terms of publishing high quality articles. The researchers have maintained a relative efficiency of 0.67 which is the second best efficiency measure after Hong Kong. Hwang and Tan (2012), for instance, presented barriers in front of having sustainable green buildings by applying a comprehensive survey in Singapore on green building project management. Overall, it appears that Asian researchers have shown more commitment on green buildings in sustainability compared with the rest of the world.

\section{Acknowledgement}

The authors would like to thank the anonymous referees for constructive comments on earlier version of this paper. 


\section{References}

Adler, N., Friedman, L., \& Sinuany-Stern, Z. (2002). Review of ranking methods in the data envelopment analysis context. European Journal of Operational Research, 140(2), 249-265.

Ali, H. H., \& Al Nsairat, S. F. (2009). Developing a green building assessment tool for developing countries-Case of Jordan. Building and Environment, 44(5), 1053-1064.

Charnes, A., Clark, C. T., Cooper, W. W., \& Golany, B. (1984). A developmental study of data envelopment analysis in measuring the efficiency of maintenance units in the US air forces. Annals of operations Research, 2(1), 95-112.

Chan, E. H., Qian, Q. K., \& Lam, P. T. (2009). The market for green building in developed Asian cities - the perspectives of building designers. Energy Policy, 37(8), 3061-3070.

Chau, C. K., Tse, M. S., \& Chung, K. Y. (2010). A choice experiment to estimate the effect of green experience on preferences and willingness-to-pay for green building attributes. Building and Environment, 45(11), 2553-2561.

Corinaldesi, V., \& Moriconi, G. (2009). Influence of mineral additions on the performance of 100\% recycled aggregate concrete. Construction and Building Materials, 23(8), 2869-2876.

Ding, G. K. (2008). Sustainable construction-The role of environmental assessment tools. Journal of Environmental Management, 86(3), 451-464.

Evins, R. (2013). A review of computational optimisation methods applied to sustainable building design. Renewable and Sustainable Energy Reviews, 22, 230-245.

Halkos, G. E., \& Salamouris, D. S. (2004). Efficiency measurement of the Greek commercial banks with the use of financial ratios: a data envelopment analysis approach. Management accounting research, 15(2), 201-224.

Hwang, B. G., \& Tan, J. S. (2012). Green building project management: obstacles and solutions for sustainable development. Sustainable Development, 20(5), 335-349.

Kuo, F. E., \& Sullivan, W. C. (2001). Aggression and violence in the inner city: Effects of environment via mental fatigue. Environment and Behavior, 33(4), 543-571.

Leaman, A., \& Bordass, B. (2007). Are users more tolerant of 'green' buildings?. Building Research \& Information, 35(6), 662-673.

Lertworasirikul, S., Fang, S. C., Joines, J. A., \& Nuttle, H. L. (2003). Fuzzy data envelopment analysis (DEA): a possibility approach. Fuzzy Sets and Systems, 139(2), 379-394.

Li, D. H., Lam, T. N., \& Wong, S. L. (2006). Lighting and energy performance for an office using high frequency dimming controls. Energy Conversion and Management, 47(9-10), 1133-1145.

Liu (2015). A green building evaluation modeling method based on eco-efficiency and data envelopment analysis. International Journal of Earth Sciences and Engineering, 8(4), 1942-1949

Liu, H., Liu, Y., Wang, H., Yang, J., \& Zhou, X. (2019). Research on the coordinated development of greenization and urbanization based on system dynamics and data envelopment analysisA case study of Tianjin. Journal of Cleaner Production, 214, 195-208.

McDonald, K. (2005). Physicist proposes new way to rank scientific output. Phys Org.

Meyer, C. (2009). The greening of the concrete industry. Cement and Concrete Composites, 31(8), 601-605.

Ortiz, O., Castells, F., \& Sonnemann, G. (2009). Sustainability in the construction industry: A review of recent developments based on LCA. Construction and Building Materials, 23(1), 28-39.

Qi, G. Y., Shen, L. Y., Zeng, S. X., \& Jorge, O. J. (2010). The drivers for contractors' green innovation: an industry perspective. Journal of Cleaner Production, 18(14), 1358-1365.

Shaikh, P. H., Nor, N. B. M., Nallagownden, P., Elamvazuthi, I., \& Ibrahim, T. (2014). A review on optimized control systems for building energy and comfort management of smart sustainable buildings. Renewable and Sustainable Energy Reviews, 34, 409-429.

Tam, C. M., Tam, V. W., \& Tsui, W. S. (2004). Green construction assessment for environmental management in the construction industry of Hong Kong. International Journal of Project Management, 22(7), 563-571.

Vyas, G. S., \& Jha, K. N. (2017). Benchmarking green building attributes to achieve cost effectiveness using a data envelopment analysis. Sustainable Cities and Society, 28, 127-134. 
Wang, W., Zmeureanu, R., \& Rivard, H. (2005). Applying multi-objective genetic algorithms in green building design optimization. Building and Environment, 40(11), 1512-1525.

Zhang, X., Platten, A., \& Shen, L. (2011). Green property development practice in China: costs and barriers. Building and environment, 46(11), 2153-2160.

Zhou, P. F., Bai, Y. H., \& Ge, D. (2013). DEA based performance evaluation model of green construction supply chain. Applied Mechanics and Materials, 291, 1064-1067.

Zuo, J., \& Zhao, Z. Y. (2014). Green building research-current status and future agenda: A review. Renewable and Sustainable Energy Reviews, 30, 271-281.

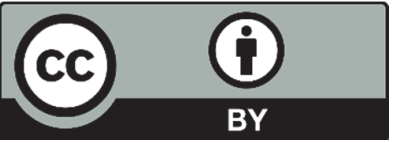

(C) 2018 by the authors; licensee Growing Science, Canada. This is an open access article distributed under the terms and conditions of the Creative Commons Attribution (CC-BY) license (http://creativecommons.org/licenses/by/4.0/). 